\title{
A CASE STUDY ON INTERNATIONAL EDUCATION COOPERATION IN COLLEGES \& UNIVERSITIES UNDER THE BELT AND ROAD INITITIATIVE (HENAN INSITUTE OF SCIENCE AND TECHNOLOGY)
}

\author{
Inna Lozynska \\ Doctor of Science in Economics, Associate Professor \\ Sumy National Agrarian University (Sumy, Ukraine) \\ ORCID: 0000-0002-8038-8484, \\ innalozynska@gmail.com
}

Wenxi Zhang

PhD student

Sumy National Agrarian University (Sumy, Ukraine) Henan Institute of Science and Technology (Henan, China)

\author{
Zhijiang Yu \\ PhD student \\ Sumy National Agrarian University (Sumy, Ukraine) \\ Henan Institute of Science and Technology (Henan, China) \\ Hongmin Yang \\ Professor in Education \\ Henan Institute of Science and Technology (Henan, China)
}

The Belt and Road Initiative provides an excellent platform for international education cooperation for Chinese universities. Henan Institute of Science and Technology (HIST) has carried out a series of in-depth cooperation on this platform, and it has also brought opportunities and challenges. This article studies the international cooperation projects carried out by HIST, and promotes international education though the Belt and Road Initiative, provides new ideas for educational cooperation among universities, enhances the level of internationalization of universities, creates high-level talents and make further efforts.

Keywords: The Belt and Road Initiative, International Education Cooperation, Chinese Universities, Chinese Higher Education. DOI: https://doi.org/10.32845/bsnau.2019.2.9

Problem statement. The Belt and Road is named by the "Silk Road Economic Belt" and the "21st Century Maritime Silk Road", provide an excellent platform for international education cooperation for Chinese higher education and universities. In July 2016, the Ministry of Education issued the "Promoting Co-construction of Educational Action of the Belt and Road"(PCEA) to push the international exchange and cooperation of university education to a new climax. Strengthening cooperation and interaction among the countries along the Belt and Road is not only an important part of the Belt and Road, but also a talent support for the construction of the Belt and Road. Under the strong promotion of the government, HIST bravely took its first step.

Analysis of current research and publications which start solving this problem and which the author refer to scientific papers of Ansar, A., Flyvbjerg, B., Budzier, A., \& Lunn, D (2016), Zhou G, Yan Y. (2015), Ding X. (2016) and others.

The main goal of research is to describe the main opportunities China's One Belt One Road in higher education.

The main results of the research. China's One Belt One Road (OBOR) strategy is the latest trend in international relations, and it is making a real impact on higher education in Central Asia. Opportunities for international education cooperation in colleges and universities

1.1 The Belt and Road Initiative provides a good platform for exchanges and cooperation between international universities.

Education is the foundation of the country's base, national prosperity, and source of people's happiness. It plays a funda- mental role in building the Belt and Road. All countries have actively worked together to develop education and work together to build the Belt and Road for the benefit of people. The Belt and Road coverage of 64 countries along the route, under the promotion of this policy, international exchanges have increased significantly, especially in China and the countries along the Belt and Road, this study chose Ukraine as a representative for research. The policy encourages countries to formulate cooperation and exchanges, talent training policies, and promote effective measures such as reduction of visa procedures, mutual recognition of credits, degree mutual recognition, mutual recognition of worldwide or regional qualifications, and vigorously develop talent exchange and cooperation among universities. The Belt and Road Initiative provides a good platform for international exchanges between universities and provides a good opportunity for China and its countries along the route.

1.2 The Belt and Road requires a large number of talents while bringing high economic benefits.

According to the "China's 2017 National Economic and Social Development Statistical Bulletin"[1], China's total foreign direct investment in 2017 (excluding banks, securities, insurance) is about 120.1 billion US dollars for countries along the Belt and Road. The amount of direct investment is 14.4 billion US dollars, about $12 \%$ of the total investment. The annual turnover of foreign contracted engineering business was approximately 168.6 billion US dollars, and the turnover of the countries along the Belt and Road was 85.5 billion US dollars, accounting for $50.7 \%$ of the turnover of foreign contracted projects. It can be seen that the 
Belt and Road Initiative has brought huge economic effects. At the same time, the demand for talents in various industries is also increasing every year. Especially for international talents, the staff dispatched to countries along the Belt and Road route need to have excellent language and technology.

1.3 With the increase income, the proportion of national investment on education has increased.

According to the "China's 2017 National Economic and Social Development Statistical Bulletin"[1], the total national education expenditure in 2017 was 163 billion US dollars, it has increased $20.2 \%$ compared with the previous year. Also in 2017, the consumption expenditure of the national residents was as high as 306 US dollars, accounting for $11.4 \%$ of the total consumption expenditure, lower than the expenditure share of food, housing and travel, ranking fourth in total consumption expenditure. It can be seen that education has a large proportion at both the national level and the individual level, and education play a pivotal role among the Chinese residents.

1.4 The Belt and Road and the Talent Promotion Policy in Henan Province

On February 10, 2019, the People's Government of Henan Province issued the "Opinions on Implementing the Innovation Driven Speed-up and Efficiency Project"[2], proposing that by 2020, the whole society's research and develop investment will strive to exceed 15 billion US dollars, the total number of hightech enterprises reached 4,500 in the Henan province. In demand of talent pooling, Henan Province will strengthen international scientific and technological cooperation and exchanges,work along the Belt and Road countries, and promote the superior technology of Henan Province. This opinion provides a better driving force for exchanges between universities and international universities in Henan Province.

Promote the establishment of scientific and technological cooperation with countries along the Belt and Road to support enterprises in Henan Province to build research and develop centers, science centers and demonstration bases in countries along Kyrgyzstan and Uzbekistan to promote the superior technology of Henan Province. Accelerate the exploration of cooperation mechanisms with 16 countries in Central and Eastern Europe, and strive for the landing the international technology center transfer to Henan. Actively promote cooperation with developed countries and regions such as the European Union, the United States, Japan, and Israel, relying on universities, research institutions, and enterprises to introduce key overseas technologies ,research and develop teams, build international cooperation research centers and laboratories.Improve scientific and technological innovation capabilities, improve the competitiveness of $\mathrm{He}$ nan Province. from HIST

1.5.International University Cooperation Experiences

After decades of experiences in development, HIST has the ability to lead the international education exchanges and cooperation in the central region. In response to the Belt and Road, the opinions of the Henan Provincial Government and the active promotion of the Xinxiang Municipal Government, the school aims to strengthen the international competitiveness, expand the scope of international influence, train international academic talents, and actively carry out international academic exchanges and cooperation. In order to serve the Belt and Road Initiative and provide talents support, we mainly start from the following aspects:
- Cultivating international professional talents

HIST is participating in the Belt and Road, actively exploring educational cooperation with countries along the Belt and Road, providing high-quality international education resources for school development, improving the school's international education level, and fostering an international perspective and educational background. With high-level international professional talents with international competitiveness,the school is cooperated with Sumy National Agrarian University(SNAU) in Ukrainian, established "Henan Institute of Science and Technology \& Sumy National Agrarian University - International Graduate School" (hereinafter referred to as the Sino-Ukrainian Graduate School), jointly train high-level talents such as masters and $\mathrm{PhD}$ students. The school is located in Ukraine,the country along the Belt and Road. The two schools have many intersections with the key disciplines in the subjects settings. The research focus is consistent in the fields of agriculture and veterinary, which provides a good premise for the deep cooperation between the two schools. On October 10, 2018, a total number of 48 students went to SNAU in Ukraine for further study and participated in the master's and doctoral programs [3].

As a central region, limited by regional economic development and insufficient funds, international exchanges and cooperation between universities are limited to short-term exchange programs or the introduction of foreign experts for short-term training. HIST as a representative of the central region, the SinoUkrainian Graduate School was created with the Belt and Road route country, effectively fill this blank. This will also solve the insufficiency of the professional internationalization development in colleges and universities, the lag of international talent development, and the low quality of Sino-foreign cooperative education projects. Promoting the training of international professionals has not only cultivated the service talents of the Belt and Road Initiative, but also improved the international competitiveness and influence of HIST.

- Promoting the speed of establishing abroad school of Chinese higher education

The active introduction of foreign educational resources has also accelerated the speed of abroad Chinese higher education. The Belt and Road Initiative not only requires the introduction of quality educational resources, but also requires the export of Chinese education industry. Due to its particularity, the possibility of the education industry output is limited. As a mainstay, HIST has established the Sino-Ukrainian Graduate School in cooperation with Ukraine, becoming the landmark project of the Belt and Road initiative of Xinxiang City, Henan Province, and accelerating the speed of abroad Chinese higher education in the central region. HIST and SNAU successfully signed 3 agreements and build 3 programs: an co-train undergraduate education program for animal medicine,the Sino-Ukrainian Graduate School, the framework of Sumy International College in HIST[3].

On the basis of this project, at the invitation of the Xinxiang Municipal Government, the delegation of the government of Sumy City, Sumy State, Ukraine, and his team of 5 people came to Xinxiang City for a friendly visit from October 24 to 28, 2018[4]. The signing of the agreement on the establishment of a sister city relationship between Xinxiang and Sumy,marks the beginning of a new phase of friendly exchanges between the two cities. It is hoped that the two cities will maintain friendly relations

Вісник Сумського національного аграрного університету Серія «Економіка і менеджмент», випуск 2 (80), 2019 
and promote exchanges and cooperation in the economy, science, technology, culture and education of the two cities.It also made active efforts to promote bilateral trade development and bilateral dialogue between China and Ukraine. training

- Conducting effective faculty member exchange and

In order to create a top-ranking university in the central region, the faculty of HIST must have solid teaching ability and excellent scientific research ability, also should have an international vision, master international advanced scientific research techniques and teaching methods, actively participate in various international teaching and research conferences. The internationalization of education can expand the international vision of college faculty, apply the new teaching models, curriculum development and foreign teaching standards of higher education, and further promote faculty to understand the frontier dynamics of the development of professional fields, thus enhancing the professional development level of faculty. At the opening of the SinoUkrainian Graduate School, HIST encouraged the teachers to participate actively. Finally, 25 faculty signed agreements with the school to participate in the doctoral program. During the study in
Ukraine, the school gave different salary according to the agreement. After graduation,they will continue their work to contribute for the front line of education.

In addition to the introduction of teachers, Ukrainian experts and teachers will be introduced into HIST also. In 2109, 10 experts and professors from SNAU will go to HIST for research and teaching, and a cooperation agreement with HIST will be signed. They will help for developing excellent international talents for HIST. Conduct teacher exchanges with international schools along the Belt and Road, explore and establish a cooperative international training cooperation mechanism through in depth cooperation with cooperative colleges, gradually build an overseas teacher training base, study each other's advantages, and enhance the professional development level of teachers.

Conclusion: The Belt and Road Initiative provides new opportunities and platforms for the development and innovation of higher education connotation. HIST grasps the general trend, seizes opportunities, and takes advantage of the trend to continuously improve the level of international education, enhance the attraction of the college in the central region, and cultivate the international technical skills talents required for the Belt and Road Initiative, make a positive contribution to the promotion of economic and social development.

\section{References:}

1. Zhou G. The Talent Support and Education Path of the "Belt \& Road" Strategy / Zhou G, Yan Y. // Educational Research. 2015. - № 10. - P.4-9.

2. Ding X. Analysis of the Opportunities and Challenges Brought by Henan Province to the "Belt \& Road" Strategy / Ding X. //Journal of Henan Finance and Taxation College. -2016. -№ 30 -P. 41-44.

3. Chinese Journal of Science and Technology and other media reports the first batch of students enrolled in Sino-Ukrainian International Graduate School - [Electronic resource]. - Access: http://www.hist.edu.cn/info/1022/15788.htm

4. Xinxiang, China and Sumy, Ukraine form an friendship city - [Electronic resource]. - Access:http://www.hnfo.gov.cn/index.php?m=content\&c=index\&a=show\&catid=72\&id=11999

Інна Лозинська, доктор економічних наук, доцент, Сумський національний аграрний університет (м. Суми, Україна)

Веньси Чжан, аспірантка, Сумський національний аграрний університет (м. Суми, Україна), Хенанський інститут науки та технології (м.Хенань, Китай)

Цзіцзянь Юй, аспірантка Сумський національний аграрний університет (м. Суми, Україна), Хенанський інститут науки та технології (м.Хенань, Китай)

Хонмин Янг, профресор кафеедри освіти, Хенанський інститут науки та технології (м.Хенань, Китай)

Дослідження міжнародного освітнього співробітництва колежів та університетів за ініціативи «Економічний пояс шовкового шляху» (Хенанський інститут науки та технології)

Ініціатива «Економічний пояс шовкового шляху» - це чудова платформа для міжнародного співробітництва в галузі освіти для китайських університетів. Iнститут науки і техніки Хенана (HIST) провів низку заходів поглибленого співробітництва на цій платформі, що принесло нові можливості та виклики. Ця стаття досліджує проекти міжнародного співробітництва, що здійснюються HIST, і просуває міжнародну освіту через ініціативу «Економічний пояс Шовкового шляху», надає нові ідеї для освітнього співробітництва між університетами, підвищує рівень інтернаціоналізації університетів, створює високі таланти і робить подальші зусилля.

Ключові слова: Ініціатива «Економічний пояс шовкового шляху», One belt-One road, Міжнародна освітня співпраця, китайські університети, китайська вища освіта.

Дата надходження до редакції: 01.02.2019 р. 